\title{
The behavior of Etawah Grade goats in early and late pregnancy period in a tropical area
}

\author{
Bayu Andri Atmoko (D). Dyah Maharani (D). Sigit Bintara (D). I Gede Suparta Budisatria (DD
}

BA Atmoko - IGS Budisatria (Corresponding author)

Department of Animal Production, Faculty of Animal

Science, Universitas Gadjah Mada, Yogyakarta, Indonesia.

email: budisatria@ugm.ac.id

\section{Maharani - S Bintara}

Department of Animal Breeding and Reproduction, Faculty of Animal Science, Universitas Gadjah Mada, Yogyakarta, Indonesia.

Received: March 10, 2020 • Accepted: March 30, 2020 - Published Online: April 03, 2020

\begin{abstract}
The objective of the study was to identify the different behavior of Etawah Grade does in early and late pregnancy period. This research using 14 head of Etawah Grade does in pregnant conditions with an age of fewer than 2 months as the early pregnancy group and gestational age of 4 to 5 months as the late pregnancy group in Farm of Faculty Animal Science, Universitas Gadjah Mada. The method used was direct observation. The goats were observed for 24 hours. The data observed were consisted of activities including time and frequency of feeding, ruminating, standing, lying, urinating and defecating. Data behavior of goats was analyzed using T-test. The results showed that the temperature and humidity of the study ranged from 25 to $31^{\circ} \mathrm{C}$ and 65 to $90 \%$, respectively. The heart rate frequency in late pregnancy higher $(P<0.05)$ than in early pregnancy conditions. There were significant differences $(P<0.05)$ on the behavior of early and late pregnancy of Etawah Grade does, in terms of frequency of feeding (17.11 \pm 1.33 and $13.61 \pm 2.85$ times/day), and average in once feeding (10.24 \pm 1.64 and $12.88 \pm 2.36$ minutes), standing duration (15.05 \pm 0.83 and $11.45 \pm 1.34$ hours/day), laying duration (9.01 \pm 0.71 and $12.54 \pm 1.34$ hours/day), average in once laying (31.32 \pm 3.6 and $47.89 \pm 5.68)$, and frequency of urination $(6.56 \pm 0.34$ and $9.55 \pm 2.01)$. The conclusion of the study is the Etawah Grade does during early pregnancy and late pregnancy has different behavior, especially on the frequency of feeding, average on once feeding, standing duration, time and average of once lying, and frequency of urination.
\end{abstract}

Keywords: animal adaptation, comfortable zone, physiological condition, temperature, tropical environment

\section{Introduction}

Some goats that can be found in Indonesia as germplasm include Kacang, Bligon Goats, Etawah grade,
Gembrong, Marica, and Samosir goats. One of the most maintained goats is the Etawah Grade (PE) Goat. PE goats were kept in Indonesia between before Dutch colonialism. In 1923 the West Dutch Government introduced Etawah or Jamnapari goats to be distributed around Purworejo, in the villages of Somongari, Tlogoguwo, Hulosobo, and Kaligesing. The presence of Etawah goats was then crossed with the Kacang goat as a local goat producing PE goats (Budisatria et al 2009).

In addition, one interesting phenomenon that occurs in PE goat farmers is the preference of farmers to choose PE goats that have black color on the head and PE goats with black and white have better productivity than other color PE goats and the price higher. The existence of this assumption is probably due to the genetic variation of the parents, namely the composition of the blood of the Etawah goat has been getting higher, so that its productivity has approached the productivity of the Etawah goat (Budisatria et al 2009).

Blakely and Bade (1998) stated that the parent must be maintained in good condition during pregnancy for the normal development of the kids they contain. Goats raised in poor conditions during pregnancy often miscarry at a young age. This is in accordance with the opinion of Field and Taylor (2008), who stated good maintenance management will protect the parent and embryo at the early pregnancy because at high temperatures can cause the embryo to die.

Maintenance of goats in pregnant conditions requires good management from feed to conditions where animals can feel comfortable expressing their behavior so that the fetus in their stomach can develop optimally. In addition, the doe can avoid stress which can affect the physiology of livestock and the condition of the womb in the fetus. Livestock can be express to be comfortably seen from the behavior of the livestock itself. De-la Lama and Matiello (2010) explain that behavior is a parameter that shows the animal adaptation and 
is the response of livestock to their environment. According to Paryadi (2002), goat behavior is influenced by two factors namely the individual factors concerned internal and external factors. Inside factors include hormones and the nervous system, while external factors are light, temperature, and humidity. Besides Bearden et al (2004) stated that physiological conditions of livestock can also influence livestock behavior.

Some types of goats have different behaviors, especially when goats are pregnant. This is in accordance with the opinion of Sarwono (2006), livestock behavior when not pregnant, namely calm, good appetite. The early signs of cattle are seen from the behavior that can be observed, namely, goats are calmer, not nervous, not aggressive, appetite increases, and often lick the cage, livestock behavior at the end of the binge will be more agitated due to pain, more often stand then lie down. Based on these conditions a study was conducted on the differences in the behavior of goats who were pregnant in early pregnancy and late pregnancy so that they could be used as a basic step in improving maintenance management and also to know the level of comfort of livestock. The aim of this study was to determine the behavior differences of Etawah Grade (PE) goats at the time of early pregnancy when the gestational age was less than 2 months and the late pregnancy when the gestational age entered the 4 to 5 month of pregnancy.

\section{Materials and Methods}

This research was carried out in the farm of the Laboratory of Meat, Draught and Companion Animal, Faculty of Animal Science, Universitas Gadjah Mada, from January to July 2019. Fourteen Etawah Grade (PE) goats with an average body weight of $39.7 \mathrm{~kg}$ and aged 3 up to 4 years in pregnant conditions with an age of fewer than 2 months as the early pregnancy group and gestational age of 4 to 5 months as the late pregnancy group. The livestock used were kept on an individual pen $\left(2 \times 1 \mathrm{~m}^{2}\right)$ and its equipped with a permanent feed bank and a bucket. The material used includes a digital clock to measure the duration of livestock behavior, thermometer $\left(\operatorname{star}_{\text {magic }}{ }^{\odot}\right.$ ) used to measure rectal temperature, thermohygrometer (HTC-2 ${ }^{\odot}$ ) is used to measure environmental temperature and also used to measure environmental humidity.

The first step is to choose the livestock to be used, and then the goat are mated. Pregnancy checks are carried out by observing the appearance of estrous after 15 to 21 days and a pregnancy check is done through the method of ultrasonography (USG) after 50 days. Goats that were declared pregnant were then observed for 24 hours. Observation of goat behavior in the early and late pregnancy conditions was carried out three times at 15, 29, 50 days and at 120,133 and 145 days gestational age respectively.
Behavior data to be taken includes eating activities (feeding time is a total time a goat for eat in one day, frequency of feeding is how many times a goat for eat in one day and the average of one feeding is how long a goat for one eat times). Water consumption is total water volume consumed by a goat in every day; rumination activities (ruminating time, a total time a goat for rumination in one day; frequency of rumination is how many times a goat for rumination in one day and; average rumination in one-time rumination is how long a goat for one rumination times). Standing activities (standing time is how many times a goat for standing in one day; frequency of standing is how many times a goat for standing in one day; the standing average is how long a goat for one standing times). Laying activities (laying time is how many times a goat for laying in one day, frequency of laying is how many times a goat for laying in one day and; average in one-time laying is how long a goat for one laying times). The frequency of urination is how many times a goat for urination in one day and the frequency of defecation is how many times a goat for defecation in one day. The behavior observations occurred for 24 hours.

In addition, measurements of physiological conditions were also carried out, including heart rate frequency, respiration frequency, and rectal temperature measured at 6:00, 12:00, 18:00, and 24:00. Data on enclosure environmental conditions are measured by a thermohygrometer for temperature and humidity every 6 hours a day at 6:00, 12:00, 18:00, and 24:00. The results of the observation data are then analyzed statistically using the t-test to differentiate goat behavior at early and late pregnancy.

\section{Results and Discussion}

\section{Temperature and Humidity}

The results of measurements of temperature and humidity of the enclosure during the study are presented in Table 1. The environmental temperature average in study location when the conditions of early and late pregnant are $27.28^{\circ} \mathrm{C}$ and $27.37^{\circ} \mathrm{C}$ respectively. The highest temperature at the early and the late of pregnancy was at 12:00. The measurement results are in accordance with Yani and Purwanto (2006), that air temperature and daily humidity in Indonesia are generally high, ranging from 24 to $34{ }^{\circ} \mathrm{C}$. The weather in Yogyakarta, Indonesia is characterized by high temperature and humidity, ranging between $25.8-34.6{ }^{\circ} \mathrm{C}$ and, 52.0 and $82.72 \%$, respectively and temperature humanity index value in Indonesia is $76.2-84.7$ (Widyobroto et al 2019). Environmental temperature is in the normal range of temperatures in Indonesia. The environmental temperature at the time of the study was at a comfortable temperature for PE goats in the tropics. A comfortable temperature for goat in tropical area between 20 and $30{ }^{\circ} \mathrm{C}$ (Borges and Rocha 2018), 
while Broom and Fraser (2015) state that the lowest critical temperature limit in small ruminants is $22{ }^{\circ} \mathrm{C}$ and the highest critical temperature limit is $35^{\circ} \mathrm{C}$.

The results of measurements of humidity are presented in Table 1 . The average humidity in the study location at the early and late of pregnancy were $82.17 \%$ and $73.08 \%$ respectively. Environmental humidity for 24 hours has fluctuations where the humidity of the environment is highest in the morning and evening and decreases in the afternoon. According to Yani and Purwanto (2006), the humidity of the environment in Indonesia is around 60 to $90 \%$. Based on the results, the environmental humidity is in a normal range. The air humidity increased along with the decrease in ambient temperature and, Collier and Collier (2012) state that environmental heat components that can affect livestock are air temperature and humidity.

Table 1 The temperature and humidity conditions at early and late pregnancy.

\begin{tabular}{cccc}
\hline Variable & Time & Early pregnancy & Late pregnancy \\
\hline Temperature $\left({ }^{\circ} \mathrm{C}\right)$ & $06: 00$ & 26.12 & 26.10 \\
& $12: 00$ & 30.43 & 31.00 \\
$18: 00$ & 27.72 & 26.73 \\
& $24: 00$ & 24.86 & 25.67 \\
Humidity $(\%)$ & Average & 27.28 & 27.37 \\
& $06: 00$ & 88.75 & 82.00 \\
& $12: 00$ & 65.25 & 65.00 \\
& $18: 00$ & 84.67 & 70.00 \\
& $24: 00$ & 90.00 & 75.33 \\
& Average & 82.17 & 73.08 \\
\hline
\end{tabular}

\section{Physiological conditions}

The results of measurements of goat physiological conditions are presented in Table 2. The goat heart rate measurements in the early pregnancy and late pregnancy conditions were $73.07 \pm 1.62$ times/minute and $75.86 \pm 1.54$ times/minute. The heart rate was significant different from the condition at the end of pregnancy $(P<0.05)$. The frequency of goat heart rate in the late pregnant condition is higher compared to the early pregnant condition. This can be caused by pregnant does in the late pregnant condition requiring more nutrients because food nutrients are carried through the bloodstream, so there is an increase in heart work in pumping blood faster. As Mauladi (2009) argues, the heart rate of pregnant animals can increase by up to 15 to $40 \%$. The frequency of goat heart rate is still in the normal range as mentioned by Frandson (1992), the normal heart rate range for goat animals is 70 to 135 times/minute. This is very good because goats can release heat received from outside the body so that goats are not stressed. Torres et al (2017) reported that a significant increase for heart rate for Dorper lamb in a tropical area between periods of the day, ranging between 79.88 and 93.11 beats/min in the morning and afternoon. The most likely explanation for this increase in number of heartbeats in the afternoon period is the heat stress caused by the increase in temperature and reduction of humidity.

The results of goat respiration measurements in the early pregnant and late pregnant conditions were $27.19 \pm 2.71$ times/minute and $26.14 \pm 2.99$ times/minute. The respiration rate was not significantly different. This can be related to the length of time lying on the late pregnancy because of the process of removing heat through lying. The measurement results showed that goat respiration for 24 hours experienced fluctuations. The highest respiration at 12.00 and the lowest respiration at 24:00. At high temperatures, the amount of respiration also increases. The goat to release heat so that it can maintain body heat does this. In accordance with the study of Torres et al (2017) which is the increase in environmental temperature, the respiration rate will increase up to 20 times/minutes which is used to maintain physiological balance in the animal's body so that the body temperature is at a normal level.

The results of rectal temperature measurements of goats in the early and late pregnant conditions were $39.15 \pm$ $0.07{ }^{\circ} \mathrm{C}$ and $39.04 \pm 0.05{ }^{\circ} \mathrm{C}$. The results of the rectal temperature measurements of the goats in the early pregnant condition and the late pregnant were not significantly different. This can be caused by the ambient temperature when the goat in the early pregnant condition does not differ greatly from the late pregnancy condition. The highest rectal temperature is $12: 00$ to $18: 00$, while the lowest rectal temperature is at 24:00. The rectal temperature will experience a decrease while in the morning to evening rectal temperature increases (Yani and Purwanto, 2006). Dukes (1993) states that normal body temperature in goats ranges from $38.5^{\circ} \mathrm{C}$ to 40.5 ${ }^{\circ} \mathrm{C}$. 
Table 2 Physiological status of the Etawah Grade does in the early and late pregnancy periods.

\begin{tabular}{|c|c|c|c|}
\hline Variable & Time & Early pregnancy & Late pregnancy \\
\hline \multicolumn{4}{|c|}{ Heart rate frequency (times/minute) } \\
\hline & 06:00 & 73.28 & 77.22 \\
\hline & $12: 00$ & 75.28 & 76.50 \\
\hline & $18: 00$ & 71,99 & 76.05 \\
\hline & $24: 00$ & 71.72 & 73.67 \\
\hline & Average & $73.07 \pm 1.62^{\mathrm{a}}$ & $75.86 \pm 1.54^{b}$ \\
\hline \multicolumn{4}{|c|}{ Respiration frequency (times/minute) $)^{\mathrm{ns}}$} \\
\hline & 06:00 & 25.28 & 23.72 \\
\hline & $12: 00$ & 30.89 & 30.17 \\
\hline & $18: 00$ & 27.55 & 26.67 \\
\hline & $24: 00$ & 25.06 & 24.00 \\
\hline & Average & $27.19 \pm 2.71$ & $26.14 \pm 2.99$ \\
\hline \multicolumn{4}{|c|}{ Rectal temperature $\left({ }^{\circ} \mathrm{C}\right)^{\mathrm{ns}}$} \\
\hline & 06:00 & 39.09 & 39.00 \\
\hline & $12: 00$ & 39.23 & 39.08 \\
\hline & $18: 00$ & 39.19 & 39.10 \\
\hline & 24:00 & 39.09 & 39.00 \\
\hline & Average & $39.15 \pm 0.07$ & $39.04 \pm 0.05$ \\
\hline
\end{tabular}

\section{Behavior}

Observations on the goats in early and late pregnancy during 24 hours are presented in Table 3 . The results showed that there were no significant differences in feeding time. The feeding time is similar to the results of Vas and Andersen (2015), which were $56.4 \pm 4.9 \%$ (2.52 hours) at the early and $38.0 \pm 3.8 \%$ (1.71 hours) at late pregnancy. The does in the late condition of pregnancy have a higher feeding time. While the feeding frequency and average in one-time feeding are the significant differences. Feeding frequency and average in onetime feeding are $17.11 \pm 1.33$ times/day and $10.24 \pm 1.64$ minutes in the early pregnant, and $13.61 \pm 2.85$ times/day and $12.88 \pm 2.36$ minutes in the late pregnant.

The feeding frequency of goat under normal conditions is 12 times a day (Houpt 2013). Based on this, the goats in the early pregnant condition in this study have a feeding frequency above the normal range, this can be caused by the appetite of the goat in the early pregnant condition is quite high. The average one-time feeding of a goat in the late pregnant condition is greater, this can be caused by the larger size of the fetus which causes the goat to eat slowly marked by the length of eating the goat which is not much different from the early pregnant condition but the frequency is lower.

The consumption of goat drinking water in the early pregnant conditions was not significantly different from the goats in the late pregnant condition. Broom and Fraser (2015) stated that consumption of drinking water for small ruminants reached 3 to 6 liters per day, while based on the study of Karstan (2006), the amount of water consumption of goat for 12 hours reached $829 \mathrm{ml}$ (0.829 liters). The amount of water consumption in early and late pregnant are below the normal range. Collier and Collier (2012) state, factors that influence of water consumption are are feed consumption, physiological conditions, species and breed, environmental conditions.

The rumination activities of goats in the early and late pregnancy are not significantly different. Rumination activities that are not different can be caused by the amount of feed, the feed form, and crude fiber content consumed, whereas at the early and end of the pregnancy the amount of feed consumed is not much different, grass given at the time of research is in the form of being chopped. This is supported by the opinion of Oetami et al (2015) that the timing of rumination is strongly influenced by the shape of feed and crude fiber content. For livestock with the supply of cut grass will shorten the rumination time. According to Broom and Fraser (2015), small Ruminants do rumination for 7 to 10 hours per day with a number of rumination periods of 15 times in 24 hours, the time needed by small ruminants in one rumination cycle varies from one minute to two hours. Based on this, rumination activities are in the normal range.

The activity of standing and laying of goat in the early and late pregnancy were significant differences in the time of standing, the time of lying, and the average in one laying. Statistical analysis showed that the length of standing and lying of the goats were $15.05 \pm 0.71$ hours/day and $9.01 \pm 0.71$ hours/day respectively in the early pregnant condition, whereas in the late pregnant $11.45 \pm 1,34$ hours/day and $12.54 \pm 1.34$ hours/day. The time of the goat laying in the late pregnant condition is higher than in the early pregnancy can be influenced by the growing size of the fetus at the end of 
pregnancy so that the goat will feel heavy and more rest. This is related to the average in one laying in the late pregnancy higher than in the early. According to Broom and Fraser (2015), goats carry out standing activities for 16 hours and 8 hours to laying. The time of standing in early and late pregnancy in this study is still lower than Andersen and Boe (2007) study, the time of goats in pregnant conditions for rest is $66 \%$ (14.4 hours) in $1 \times 1 \mathrm{~m}^{2}$ pen.

Table 3 The behaviors of Etawah Grade does in the early and late pregnancy periods during 24 hours.

\begin{tabular}{|c|c|c|}
\hline Variable & Early pregnancy & Late pregnancy \\
\hline Feeding time (hours/day) ${ }^{\mathrm{ns}}$ & $2.90 \pm 0.28$ & $2.85 \pm 0.42$ \\
\hline Frequency of feeding (times/day) & $17.11 \pm 1.33^{\mathrm{a}}$ & $13.61 \pm 2.85^{\mathrm{b}}$ \\
\hline Average in one time feeding (minutes) & $10.24 \pm 1.64^{\mathrm{a}}$ & $12.88 \pm 2.36^{\mathrm{b}}$ \\
\hline Water consumption (liters/day) ${ }^{\text {ns }}$ & $2.34 \pm 0.76$ & $2.45 \pm 0,45$ \\
\hline 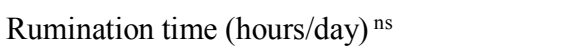 & $5.44 \pm 0.23$ & $5.66 \pm 0.72$ \\
\hline Frequency of rumination (times/day) ${ }^{\mathrm{ns}}$ & $15.33 \pm 0.66$ & $16.39 \pm 2.11$ \\
\hline Average in one time rumination (minutes) ${ }^{\mathrm{ns}}$ & $21.30 \pm 1.38$ & $20.74 \pm 0.79$ \\
\hline Standing (hours/day) & $15.05 \pm 0.71^{\mathrm{a}}$ & $11.45 \pm 1.34^{\mathrm{b}}$ \\
\hline Frequency of standing (times/day) $)^{\mathrm{ns}}$ & $19.11 \pm 1.44$ & $17.39 \pm 1.76$ \\
\hline Average in one time standing (minutes) ${ }^{\mathrm{ns}}$ & $47.43 \pm 4.09$ & $43.93 \pm 6.83$ \\
\hline Laying time (hours/day) & $9.01 \pm 0,71^{\mathrm{a}}$ & $12.54 \pm 1.34^{\mathrm{b}}$ \\
\hline Frequency of laying(times/day $)^{\mathrm{ns}}$ & $17.39 \pm 1.75$ & $15,67 \pm 1.56$ \\
\hline Average in one time laying (minutes) & $31.32 \pm 3.60^{\mathrm{a}}$ & $47.89 \pm 5.68^{\mathrm{b}}$ \\
\hline Frequency of urination (times/day) & $6.56 \pm 0.34^{\mathrm{a}}$ & $9.55 \pm 2.01^{\mathrm{b}}$ \\
\hline Frequency of defecation (times/day) ${ }^{\mathrm{ns}}$ & $4.68 \pm 1.13$ & $5.22 \pm 2.22$ \\
\hline
\end{tabular}

$\overline{\mathrm{a}, \mathrm{b}}$ Different superscripts on the same line show significant differences $(P<0,05)$.

${ }^{\text {ns }}$ Non Significant.

The frequency of standing, averaging in one stand and lying down in the early pregnant condition were not significantly different, but the difference was seen in the average in one laying. The mean in one standing and lying is $47.43 \pm 4.09$ minutes and $31.32 \pm 3.6$ minutes in the early pregnant condition and $43.93 \pm 6.83$ minutes and $47.89 \pm 5.68$ minutes in the late pregnant condition. Broom and Fraser (2015) stated that the goats in standing and laying down seven times with laytime of 43 minutes. The frequency and average of one standing or laying can be influenced by the high frequency of urination in the late pregnant condition so that the goat is more often to stand and lie down because urination is done by standing. According to the opinion of Broom and Fraser (2015) ruminants if they will urinate by standing and lifting the tail. The average of laying in the late pregnant condition is in accordance with the normal range and increased based on the aged of pregnancy. Vas and Andersen (2015), reported the time of laying the early, middle, and late pregnancy period that is $18.9 \pm 4.6 \%$ or 0.85 hours; $26.6 \pm 4.4 \%$ or 1.2 hours; and $28.9 \pm 3.2 \%$ or 1.3 hours from a total observation of 4.5 hours.

The frequency of urination of the early pregnancy and late pregnancy goats was $6.56 \pm 0.34$ times/day and $9.55 \pm 2.01$ times/day. Statistical analysis shows there are significant differences. This can be caused by the condition of the fetus that is getting bigger so that the urinary bladder is more frequent. In late pregnancy is when the growth of the fetus grows. When the fetus grows and the uterus develops around it, the mother's bladder becomes depressed and pressed which will cause frequent urination. Broom and Fraser (2015) stated that the amount of urination of small ruminants in nonpregnant conditions was less than 8 times whereas in pregnant conditions it was 9 to 13 times. Guyton and John (2006) state that the urination rate at the time of pregnancy will usually increase this because of an increase in the drinkable fluid and increased load or product excretion. In addition, urinary tract function changes. First, the renal tubule in the capacity of sodium, chloride, and water reabsorption increases $50 \%$ for the increased production of steroid hormones in the placenta and adrenal cortex. Second, the filtration rate in glomerulus increases by $50 \%$ during pregnancy, which will tend to increase the excretion rate of water and electrolytes in the urine.

The frequency of defecation was not significant different between goats in the early and late pregnancy conditions (4.68 \pm 1.13 and 5.22 \pm 2.22 times/day, respectively). The feed ingredients consumed by the goats in their early and late pregnancy conditions not much different could have 
caused this. Broom and Fraser (2015) stated that the number of small ruminants in one day was 6 to 8 times. The results of the study when compared with the literature are still below the normal range. Broom and Fraser (2015) state that the factors that influence livestock defecation are the quality of digestible feed ingredients, the temperature of the environment, and the condition of the individual itself. The environmental condition was at a comfortable temperature for PE goats. This causes environmental conditions do not directly affect the behavior of goats, while pregnancy from goats can affect behavior such as feeding frequency, average in one-time feeding, time of standing and laying, average in one time laying.

\section{Conclusions}

It was concluded that the physiological condition of goats could affect behavior such as the frequency of feeding, average of feeding time, time of standing and laying, average of one time laying, frequency of urination, and frequency of heart rate. The Etawah Grade does, in late pregnancy, has a longer period of laying and frequency of urination than early pregnancy.

\section{Acknowledgements}

The study was supported by the grant from Ministry of Research, Technology and Higher Education of Indonesia in PMDSU (Master Program of Education Leading to Doctoral Degree for Excellent Graduates) program scheme with contract no. 1996/UN1/DITLIT/DIT-LIT/LT/2017.

\section{Conflict of Interest}

The authors declare no conflict of interest.

\section{References}

Andersen IL, Boe KE (2007) Resting pattern and social interactions in goats-The impact of size and organisation of lying space. Applied Animal Behaviour Science 108-89-103.

Bearden HJ, Fuquay JW, Willard ST (2004) Applied Animal Reproduction. $6^{\text {th }}$ ed. New Jersey, Prentice Hall, Upper Saddle River.

Blakely J, Bade DH (1998) Ilmu Peternakan (Animal Sicence). $4^{\text {th }}$ ed. Gadjah Mada University Press, Yogyakarta.

Borges LS, Rocha FSB (2018) Simple physiological indicators of young goat bred in extensive system. Journal of Animal Behaviour and Biometeorology 6:48-51.

Broom D M, Fraser AF (2015) Domestic Animal Behaviour and Welfare. $5^{\text {th }}$ ed. Gutenberg Press. Tarxien, Malta.

Budisatria, IGS, Triwidayati D, Suhartanto B, Kustantinah, Mulyadi, Santosa KA (2009) Germ Plasma of Goats in Indonesia. CV- Bawah Sadar, Yogyakarta.

Budisatria, IGS, Panjono, Agus A (2014) Behavior study of male Bligon kept on individual and colony housing. Proceedings of the $16^{\text {th }}$ AAAP Animal Science Congress. Faculty of Animal Science. Universitas Gadjah Mada, Yogyakarta.
Collier RJ, Collier JL (2012) Environmental Physiology of Livestock. Wiley-Blackwell, Singapore.

De-la Lama GCM, Mattiello S (2010) The importance of social behaviour for goat welfare in livestock farming. Small Ruminant Research 90:1-10.

Dukes HH (1993) Dukes' Physiology Of Domestic Animal. 11 $1^{\text {th }}$ ed. Comstock Publishing Associates. Cornell University Press. Ithaca and London.

Field TG, Taylor RE (2008) Scientific Farm Animal Production $9^{\text {th }}$ ed. Pearson Prentice Hall. New Jersey, USA.

Guyton AC, Hall JE (2006). Textbook of Medical Physiology. $11^{\text {th }}$ ed. Elsevier Saunders. Elsiever inc.

Houpt KA (2013). Domestic Animal Behaviour for Veteriner and Animal Scientists. $5^{\text {th }}$ ed. Wiley Blackwell, Singapore.

Karstan AH (2006) Respon fisiologi ternak kambing yang dikandangkan dan ditambatkan terhadap konsumsi pakan dan air minum. Jurnal Agroforestri. 1:63-73.

Manik DFM (2015) Perilaku makan kambing peranakan etawah bunting dan pengaruhnya terhadap konsumsi, kecernaan bahan kering, dan berat badan. Thesis for BSc. Faculty of Animal Science, IPB University. Bogor.

Mauladi AH (2009) Suhu tubuh, frekuensi jantung, dan nafas induk Sapi Friesian Holstein bunting yang divaksin dengan vaksin Avian Influenza H5N1. Thesis for BSc. Faculty of Veterinary Science, IPB University. Bogor.

Oetami N, Heriyadi D, Dwi CB (2015) Behavior of deglutition, regurgitation, redeglutation, rumination and the rumination time of Garut Sheep in the cage. Student e-Journal. Faculty of Animal Science. Padjajaran University. 3:1-10

Paryadi A. (2002) Tingkah laku makan kambing lokal dewasa yang digembalakan di lahan gambut hutan sekuder Palangkaraya, Kalimantan Tengah. Skripsi Sarjana Peternakan. Fakultas Peternakan IPB. Bogor.

Sarwono (2006) Beternak Kambing Unggul. Penebar Swadaya, Jakarta.

Torres TS, Silva. LO, Borges LS, Sena LS, Moreira AL, Machado LPM, Cardoso JPB, Junior AS (2017) Behavioral and thermoregulatory characteristics of Dorper Sheep. Journal of Animal Behaviour and Biometeorology 5:85-90.

Vas J, Andersen IL (2015) Density-dependent spacing behaviour andactivity budget in pregnant, domestic goats (Capra hircus). PLoS ONE 10:1-17

Widyobroto BP, Rochijan, Novandi CT, Astuti, A (2019) Microenvironment identification and the feed availability for dairy cows during dry and wet seasons in the main dairy areas of Yogyakarta-Indonesia. Journal of Animal Behaviour and Biometeorology 7:86-91.

Yani A, Purwanto BP (2006) Pengaruh Iklim Mikro Terhadap Respon Fisiologis Sapi Peranakan Frisian Holstein dan Modifikasi Lingkungan Untuk Meningkatkan Produktivitasnya. Media Peternakan. 29:35-46. 